\title{
MOŻLIWOŚCI WSPÓŁPRACY FIRM Z KAPITAŁEM ZAGRANICZNYM Z CENTRAMI TRANSFERU TECHNOLOGII
}

\begin{abstract}
Umiędzynarodowienie działalności gospodarczej przez inwestycje zagraniczne sprzyja racjonalnemu wykorzystaniu posiadanych zasobów i technologii. Zagraniczne inwestycje bezpośrednie (BIZ) stanowiące integralną część otwartego międzynarodowego systemu gospodarczego są istotnym katalizatorem tych zmian. Istotą bezpośrednich inwestycji zagranicznych jest wywieranie trwałego wpływu inwestora bezpośredniego na podmiot gospodarczy w innym kraju, co zarazem powoduje długotrwały związek między inwestorem a podmiotem inwestycji z korzyścią dla regionów i gospodarek. Transfer myśli naukowo-technicznej, wiedzy z wykorzystaniem BIZ wynika $\mathrm{z}$ faktu podejmowania przez te podmioty działalności gospodarczej w istotnej mierze bazującej na wykorzystaniu nowoczesnych technik i metod wytwarzania, organizacji, czy sposobów zarządzania przedsiębiorstwem.

Celem niniejszego opracowania jest wskazanie na możliwości współpracy firm z kapitałem zagranicznym z centrami transferu technologii. Na bazie dokonanej analizy pozyskanego materiału teoretyczno-empirycznego stwierdzono, iż w procesie transferu technologii i wiedzy oraz rozwoju innowacji kluczową rolę odgrywają centra transferu technologii, a przedsiębiorstwami, które w sposób dynamiczny wprowadzają nowe rozwiązania techniczne i technologiczne są podmioty z kapitałem zagranicznym. Współpraca firm z kapitałem zagranicznym z centrami transferu technologii może wpłynąć pozytywnie na wsparcie i aktywizację biznesową i naukową środowiska naukowego oraz rozwój i podniesienie innowacyjności regionu i gospodarki.

Niniejsze opracowanie należy traktować wyłącznie jako punkt wyjścia, czy też niewielki element składowy badań nad możliwościami współpracy firm z kapitałem zagranicznych a centrami transferu technologii. Złożoność procesów transferu technologii i wynikająca stąd trudność ich pomiaru oraz interpretacji powodują, że w opracowaniu zidentyfikowane zostały możliwości komercjalizacji dotyczące z jednej strony wymiernych efektów instytucjonalnych procesu budowy podstaw współpracy nauka - biznes, biznes - nauka oraz niewykorzystanych w opinii autorów (brak wyników badań krajowych w tym zakresie) zasobów biznesowych firm z kapitałem zagranicznym w procesie transferu technologii i wiedzy uczelni krajowych. Niniejsze rozważania mają charakter opisowo-analityczny i stanowią wstęp do dalszych badań empirycznych nad możliwościami współpracy przedsiębiorstw z kapitałem zagranicznym z centrami transferu technologii w Polsce.
\end{abstract}

Słowa kluczowe: przedsiębiorstwa z kapitałem zagranicznym, transfer technologii, centra transferu technologii.

\footnotetext{
${ }^{1}$ Dr inż. Małgorzata Lechwar, Wydział Ekonomii, Uniwersytet Rzeszowski, ul. Ćwiklińskiej 2, 35-601 Rzeszów, lechwarm@ur.edu.pl.

${ }^{2}$ Dr Katarzyna Puchalska, Wydział Ekonomii, Uniwersytet Rzeszowski, ul. Ćwiklińskiej 2, 35-601 Rzeszów, k_puch@ur.edu.pl.
} 


\section{WSTEP}

Podmiotami, które w sposób dynamiczny wprowadzają nowe rozwiązania techniczne $\mathrm{i}$ technologiczne, czy nowe wzorce w szeroko pojętym zarządzaniu są podmioty z kapitałem zagranicznym. Kapitał zagraniczny to kapitał wniesiony do przedsiębiorstwa, w postaci środków finansowych (gotówka, akcje, obligacje), rzeczowych aktywów trwałych (maszyny, urządzenia, środki transportu, nieruchomości) oraz wartości niematerialnych i prawnych (patenty, licencje itp.) przez podmiot zagraniczny (osoba fizyczna nieposiadająca obywatelstwa polskiego; osoba prawna z siedzibą za granicą; jednostka organizacyjna niebędąca osobą prawną z siedzibą za granicą). ${ }^{3}$

Liczne badania dowodzą ${ }^{4}$, że przyspieszenie umiędzynarodowienia działalności gospodarczej przez inwestycje zagraniczne sprzyja racjonalnemu użytkowaniu kapitału, pracy i technologii, a przekształcone w drodze inwestycji zagranicznych przedsiębiorstwa uzyskują poprawę sytuacji finansowej ${ }^{5}$. Większość strumieni inwestycyjnych wypływa z krajów rozwiniętych stąd przyczyniają się one w szczególny sposób do realizacji innowacyjnych projektów inwestycyjnych. Przede wszystkim zagraniczne inwestycje bezpośrednie (BIZ), które stanowią integralną część otwartego międzynarodowego systemu gospodarczego są często głównym katalizatorem zmian. Jednakże korzyści płynące z zagranicznych inwestycji bezpośrednich nie narastają w sposób automatyczny i równomierny w poszczególnych krajach, sektorach oraz społecznościach lokalnych. W wielu krajach przyciąganie zagranicznych inwestycji bezpośrednich oraz czerpanie $\mathrm{z}$ nich pełnych korzyści w zakresie rozwoju jest kształtowane przez politykę krajową ${ }^{6}$. Celem bezpośrednich inwestycji zagranicznych jest wywieranie trwałego wpływu inwestora bezpośredniego na podmiot gospodarczy w innym kraju. Bezpośrednie inwestycje zagraniczne mogą przyjmować trzy zasadnicze formy: fuzje, przejęcia i inwestycje greenfield ${ }^{7}$. Te ostatnie są szczególnie korzystne ze względu na budowę podmiotu od podstaw na terenie, kraju inwestycji. Literatura przedmiotu wskazuje, że BIZ dość wcześnie zostały zidentyfikowane jako potencjalny kanał transferu technologii i wiedzy. Jednocześnie są traktowane jako zjawisko zachodzące we współczesnej gospodarce światowej wymagające rozpoznania w procesie badań ${ }^{8}$.

${ }^{3}$ Działalność gospodarcza podmiotów z kapitałem zagranicznym w 2015 r., Informacje i opracowania statystyczne, GUS, Warszawa 2016, s. 10, http://stat.gov.pl/obszary-tematyczne/podmioty-gospodarcze-wyniki-finansowe/przedsiebiorstwa-niefinansowe/dzialalnosc-gospodarcza-podmiotow-z-kapitalem-zagranicznym-w-2015-r-,4,11.html?contrast=black-yellow.

${ }^{4}$ A. Wancio, Wptyw bezpośrednich inwestycji zagranicznych na innowacyjność gospodarek wschodzacych. Przypadek Indii, Warszawa 2015, s. 3, http://kolegia.sgh.waw.pl/pl/KGS/postepowania/doktoraty/Documents/Wancio\%20-\%20streszczenie\%20polskie.pdf; A. Szewc-Rogalska, M. Leszczyńska, Kapitat zagraniczny jako czynnik rozwoju $i$ modernizacji gospodarki, http://ur.edu.pl/pliki/Zeszyt19/15.pdf.

5 B. Wyżnikiewicz, Korzyści z obcego kapitatu, „Prawo i Gospodarka”, nr 54/2001, s. 7.

${ }^{6}$ Foreign direct investment for development. Maximising benefits, minimising costs, Overview, https://www.oecd.org/investment/investmentfordevelopment/1959815.pdf.

${ }^{7}$ M. Olifirowicz (red.), Bezpośrednie inwestycje zagraniczne na świecie $i$ w Polsce: tendencje, determinanty $i$ wptyw na gospodarke, Warszawa 2002, s. 13-14.

${ }^{8}$ A. Wancio, Wptyw bezpośrednich inwestycji..., s. 3; J. Wiśniewska, Bezpośrednie inwestycje zagraniczne $w$ procesie kreowania innowacyjności i konkurencyjności przedsiębiorstw, Studia i Prace Wydziału Nauk Ekonomicznych i Zarządzania, nr 21, http://www.wneiz.pl/nauka_wneiz/sip/sip212011/SiP-21-5.pdf. 
Potencjalnie współpraca firm z kapitałem zagranicznym z otoczeniem naukowo-badawczym pozwala na nawiązanie nowych kontaktów, pozyskanie nowych rozwiązań technologicznych i innowacyjnych, a oczekiwaną wartością dodaną tej współpracy jest podniesienie poziomu innowacyjności całego regionu, co sprzyja budowie gospodarki opartej na wie$\mathrm{dzy}^{9}$. Istotną rolę $\mathrm{w}$ procesie transferu technologii i wiedzy oraz rozwoju innowacji na styku nauka-biznes odgrywają centra transferu technologii ${ }^{10}$. Jest to związane $\mathrm{z}$ dwoma trendami w rozwoju gospodarki światowej, tj. globalizacją i regionalizacją. Procesy globalizacji i regionalizacji mogą prowadzić do przejmowania kompetencji w zakresie społeczno-gospodarczym przez instytucje nie tylko ponadnarodowe, ale również regionalne i lokalne ${ }^{11}$. W coraz większym zakresie obserwuje się tendencję do rozwoju kooperacji w kwestii B+R. Taka współpraca może być oparta na różnych rodzajach umów i przybierać formę aliansu strategicznego, czy mieć charakter instytucjonalny ${ }^{12}$.

Celem niniejszego opracowania jest wskazanie na istniejące możliwości współpracy firm z kapitałem zagranicznym z centrami transferu technologii.

Przyjęty obszar badawczy jest powiązany z faktem, iż zgodnie z ustawą Prawo o szkolnictwie wyższym ${ }^{13}$, w celu lepszego wykorzystania potencjału intelektualnego i technicznego uczelni oraz transferu wyników prac naukowych do gospodarki uczelnie mogą prowadzić akademickie inkubatory przedsiębiorczości oraz centra transferu technologii. Centra transferu technologii mają być wyspecjalizowanymi instytucjami transferu technologii. Ich tworzenie służyć ma realizacji ustawowego wymogu, by uczelnie współpracowały z otoczeniem gospodarczym, w szczególności przez sprzedaż lub nieodpłatne przekazywanie wyników badań i prac rozwojowych przedsiębiorcom oraz szerzenie idei przedsiębiorczości w środowisku akademickim.

Opracowanie ma charakter opisowo-analityczny i opiera się na metodzie desk research. Zakres czasowy prowadzonej analizy obejmuje lata 2012-2015.

\section{INSTYTUCJONALIZACJA TRANSFERU TECHNOLOGII I WIEDZY - CENTRA TRANSFERU TECHNOLOGII}

Instytucjonalizacja jest cechą wyróżniającą rozwój wszystkich typów, rodzajów i form stosunków społecznych. Proces instytucjonalizacji oznacza ich unowocześnianie i stabilizowanie. Pojęcie instytucjonalizacja wywodzi się ze starołacińskiego terminu institutio (urządzenie, zwyczaj). Ilościowy i jakościowy rozwój instytucji podnosi znaczenie procesów instytucjonalizacji w życiu społeczeństw. Procesy te uznane zostały przez teoretyków za najważniejsze przejawy zmienności w całej historii ludzkich społeczeństw. Instytucjo-

\footnotetext{
9 Wspótpraca nauki i biznesu. Doświadczenia i dobre praktyki wybranych projektów w ramach Programu Operacyjnego Innowacyjna Gospodarka na lata 2007-2013; K. Bromski (red.), PARP, Warszawa 2013, https://www.parp.gov.pl/images/PARP_publications/pdf/18863.pdf.

${ }^{10}$ K.B. Matusiak, J. Guliński, System transferu technologii i komercjalizacja wiedzy - sity motoryczne i bariery, Polska Agencja Rozwoju Przedsiębiorczości, PARP, Poznań-Łódź-WrocławWarszawa 2010, s. 40-48, http://www.kigeit.org.pl/FTP/PRCIP/Literatura/072_System_transferu_technologii_i_komercjalizacji_wiedzy_w_Polsce_PARP_2010.pdf.

${ }^{11}$ I. Pietrzyk, Polityka regionalna Unii Europejskiej $i$ regiony $w$ państwach członkowskich, Warszawa 2002 , s. 16-27.

12 J. Rymarczyk, Biznes międzynarodowy, Warszawa 2012, s. 428.

${ }^{13}$ Ustawa z dnia 27 lipca 2005 r. Prawo o szkolnictwie wyższym (Dz.U. z 2005 r., nr 164, poz. 1365).
} 
nalizacja stanowi źródło zmian i ewolucji danej zbiorowości. Prowadzi do tworzenia trwałych i celowo współdziałających zespołów działań oraz interakcji. W ten sposób powstają nowe sposoby komunikowania wzajemnego, tworząc trwałe ramy rozpatrywania i rozwiązywania wspólnych problemów ${ }^{14}$.

Europejskie i krajowe dokumenty strategiczne oraz wyzwania ekonomiczne gospodarek europejskich stanowią główną przesłankę w zakresie budowy głębszych relacji między sferą nauki i biznesu skutkującą między innymi procesem komercjalizacji wyników prac badawczo-rozwojowych.

Szkolnictwo wyższe w perspektywie 2020 roku bierze pod uwagę następujące procesy bezpośrednio dotyczące przyszłości szkolnictwa wyższego i badań naukowych w Europie $^{15}$ :

- formowanie się Europejskiego Obszaru Szkolnictwa Wyższego (European Higher Education Area);

- formowanie się Europejskiej Przestrzeni Badawczej (European Research Area);

- formowanie się agendy modernizacyjnej uniwersytetów europejskich na poziomie Komisji Europejskiej;

- wprowadzanie w życie unijnej strategii lizbońskiej (która została formalnie zastąpiona przez strategię Europa 2020) na rzecz wzrostu gospodarczego i zatrudnienia, w ramach której kluczem do dobrobytu państw europejskich jest promowanie gospodarek i społeczeństw „opartych na wiedzy”, realizowane w ramach trójkąta edukacja - badania naukowe - innowacje, w którym kluczową rolę odgrywają systemy szkolnictwa wyższego i badań naukowych.

Wymaga to istotnego przeorientowania instytucjonalnego w uczelniach, w zakresie norm i rozwiązań organizacyjnych ${ }^{16}$, pozwalającego na pełny ich udział w procesie dynamizowania wzrostu i rozwoju gospodarczego bazującego na założeniach gospodarki opartej na wiedzy.

Z kolei rekomendacje Rady Unii Europejskiej ds. Edukacji z 2011 roku wskazują, że ${ }^{17}$ :

- skuteczna walka z kryzysem ekonomicznym wymaga, aby państwa UE dążyły do lepszej współpracy uczelni z gospodarką,

- konieczne jest silniejsze powiązanie szkolnictwa wyższego z badaniami,

- szkoły wyższe winny podejmować partnerstwo i współpracę z przedsiębiorcami, a państwa członkowskie zacieśniać powiązania między uczelniami, pracodawcami i instytucjami rynku pracy.

Jest to tym bardziej istotne, że przeprowadzone w polskiej gospodarce analizy wskazują, że w niewielkim stopniu udało jej się wejść na ścieżkę rozwoju opartego na innowacjach i wiedzy, która tylko w ten sposób może prowadzić do wzrostu i rozwojowego kraju i dołączenia do grupy zamożnych krajów wysoko rozwiniętych. Innowacyjność polskiej

${ }^{14} \mathrm{http} / / /$ stosunki-miedzynarodowe.pl/slownik/55-i/539-instytucjonalizacja.

${ }^{15} \mathrm{M}$. Kwiek, Polskie szkolnictwo wyższe a transformacje uniwersytetów w Europie. https://repozytorium.amu.edu.pl/jspui/bitstream/10593/10335/1/Kwiek_Appendix_2010.pdf.

${ }_{16} \mathrm{~W}$ tym w oparciu o akademickie inkubatory przedsiębiorczości oraz centra transferu technologii.

${ }^{17}$ Nowoczesne uczelnie rada na kryzys, Ministerstwo Nauki i Szkolnictwa Wyższego, https:// www.google.pl/search?q=Nowoczesne+uczelnie+rad\%C4\%85+na+kryzys\&oq=Nowoczesne+ +uczelnie+rad\%C4\%85+na+kryzys\&aqs=chrome..69i57.995j0j7\&sourceid=chrome\&espv= $=210 \&$ es_sm $=122 \&$ ie $=$ UTF- 8 . 
gospodarki na tle krajów świata i Unii Europejskiej jest niska ${ }^{18}$. W globalnym rankingu innowacyjności „The Global Innovation Index 2017” pośród 127 krajów Polska zajęła 38. pozycję, uzyskując 41,99 pkt (na możliwych 100 pkt), a wydatki brutto na B + R jako \% PKB wyniosły $1.0^{19}$. W Unii Europejskiej Polska jest umiarkowanym innowatorem. Summary Innovation Index dla Polski wynosił w 2010 r. 52,8\%, a w 2016 r. 54,8\% w stosunku do średniej UE $\mathrm{UE}^{20}$.

W Polsce, w związku z brakiem rynku badań naukowych, do głównych zadań polityki regulacji tego rynku zalicza $\operatorname{się}^{21}$ :

- wpływ na zachowania głównych aktorów rynku: wynalazców, przedsiębiorców, uczelni/instytutów, inwestorów, brokerów nauki (tworzenie właściwych bodźców skłaniających do aktywnego uczestnictwa w rynku);

- $\quad$ wpływ na wymianę informacji między aktorami rynku;

- wpływ na dostępność kapitału celem finansowania innowacji;

- wpływ na relacje pomiędzy uczestnikami rynku, np. pomiędzy wynalazcą i uczelnią/instytutem, przedsiębiorcą i inwestorem;

- wpływ na sam proces komercjalizacji, w tym ewentualne wykorzystanie środków publicznych dla jego wsparcia.

W przypadku uczelni zasadna stała się więc budowa struktury ,układu instytucjonalnego transferu wiedzy". W ustawie Prawo o szkolnictwie wyższym zapisano, że centrum transferu technologii tworzy się w celu sprzedaży lub nieodpłatnego przekazywania wyników badań i prac rozwojowych do gospodarki. Tego typu jednostki transferu stanowią istotny element polityki szkoły wyższej, umożliwiający większe otwarcie na kontakty z praktyką gospodarczą oraz uczestnictwo w regionalnych działaniach, stymulujących rozwój ekonomiczny. Współpraca między sferą nauki a przedsiębiorstwami może odbywać się w formie:

- zamówień na realizację prac badawczo-rozwojowych, tzw. badania zlecone,

- wspólnych inicjatyw badawczych,

- inwestycji bezpośrednich, joint-ventures, firm typu spin-off i spin-out,

- patentów, licencji, know-how,

- wymiany pracowników, w tym praktyki i staże zawodowe pracowników naukowych w przedsiębiorstwach,

- struktur sieciowych np. klastry, w skład których wchodzą uczelnie i przedsiębiorstwa.

${ }^{18}$ Potencjat innowacyjny gospodarki: uwarunkowania, determinanty, perspektywy, NBP, Warszawa 2016, s. 29-40, 92, https://www.nbp.pl/aktualnosci/wiadomosci_2016/20160530_Raport_innowacyjnosc.pdf; Polska 2015. Raport o stanie gospodarki, Ministerstwo Gospodarki, Warszawa 2015, s. 255-259, https://www.mr.gov.pl/media/15346/Raport_o_stanie_gospodarki_2015_pl.pdf; P. Zadura-Lichota (red.), Innowacyjna przedsiębiorczość w Polsce. Odkryty i ukryty potencjat polskiej innowacyjności, PARP 2015, https://www.parp.gov.pl/files/74/81/806/22522.pdf. Przedsiębiorczość w Polsce, Warszawa 2016, s. 39-43, https://www.mr.gov.pl/media/27643/Przedsiebiorczosc_w_Polsce.pdf.

${ }^{19}$ The Global Innovation Index 2017, Innovation Feeding the World, s. 44, 277, https://www.globalinnovationindex.org/.

${ }^{20}$ European Innovation Scoreboard 2017, s. 62, http://ec.europa.eu/DocsRoom/documents/24829.

${ }^{21}$ W.M. Orłowski, Komercjalizacja badań naukowych w Polsce. Bariery i możliwości ich przełamania, Warszawa 2013, s. 36, http://www.biznes.edu.pl/upload/files/komercjalizacja-badan-naukowych-w-polsce---prof.-w.-orlowski.pdf. 
Centra transferu technologii, to nienastawione na zysk jednostki realizujące projekty wsparcia transferu i komercjalizacji technologii. Działalność centrów na styku sfery nauki i biznesu ma przyczynić się do wzrostu wykorzystania nowoczesnych technologii przez działające w regionie małe i średnie firmy, a tym samym przyczynić się do podniesienia innowacyjności i konkurencyjności przedsiębiorstw oraz regionów. Centra mają zapewniać swego rodzaju bufor, pozwalający na pogodzenie komercjalizacji, badań naukowych i działalności dydaktycznej na uczelniach. Pierwsze centra transferu technologii zaczęły powstawać w latach 60. XX w. w Stanach Zjednoczonych oraz Wielkiej Brytanii. Najczęściej były to uczelniane działy transferu technologii ${ }^{22}$. W Polsce centra pojawiły się na początku lat 90. Wzrost zainteresowania nimi nastąpił dopiero po 1996 r., w wyniku uruchomienia przez Fundację na rzecz Nauki Polskiej programu finansowania innowacji technologicznych „Income". W połowie 2010 r. w Polsce było 90 centrów. Wzrost liczby centrów miał związek z uchwaleniem w 2005 r. ustawy Prawo o szkolnictwie wyższym gdzie zapisem, że centrum transferu technologii tworzy się w celu sprzedaży lub nieodpłatnego przekazywania wyników badań i prac rozwojowych do gospodarki, zalegalizowano tego typu podmioty w strukturach szkół wyższych. Do podstawowych celów działalności uczelnianych centrów transferu zalicza się między innymi ${ }^{23}$ :

- rozwijanie sieci kontaktów między światem nauki i biznesu, animację transferu technologii,

- upowszechnianie osiągnięć naukowych i prowadzenie uczelnianej polityki komercjalizacji wyników badań,

- zarządzanie własnością intelektualną powstałą w instytucjach naukowo-badawczych, uczelniach,

- promocję instytucji naukowo-badawczych, uczelni, zespołów badawczych i ich osiągnięć,

- doradztwo, szkolenia i informację w zakresie realizacji przedsięwzięć innowacyjnych, przedsiębiorczości, własności intelektualnej itp. zagadnień, dla świata nauki i biznesu,

- tworzenie baz danych,

- ocenę potencjału komercyjnego i innowacyjnego nowych rozwiązań technologicznych, produktowych i organizacyjnych,

- identyfikację potrzeb innowacyjnych podmiotów gospodarczych tzw. audyt technologiczny,

- współpracę z potencjalnymi inwestorami,

- poszukiwanie źródeł finansowania badań.

Do zadań centrów należy informowanie o prowadzonych na uczelniach pracach badawczych oraz poszukiwanie możliwości komercjalizacji wyników, poszukiwanie partnerów lub zleceniodawców nowych projektów. Centra działają na zdecydowanej większości wyższych uczelni. Głównym celem działalności centrów transferu technologii jest szeroko rozumiana eksploatacja i komercjalizacja wiedzy. Centra, jako główne cele działalności mogą wykazywać ${ }^{24}$ :

${ }^{22}$ Centra Transferu Technologii, http://www.pi.gov.pl/iob/chapter_86470.asp.

${ }^{23}$ Innowacje i transfer technologii. Stownik pojęć, red. K.B. Matusiak, Warszawa 2011, s. 31-34, https://www.parp.gov.pl/files/74/81/469/12812.pdf.

${ }^{24}$ Centra Transferu Technologii, http://www.pi.gov.pl/iob/chapter_86470.asp. 
- komercjalizację i transfer technologii (transfer technologii do gospodarki, komercjalizacja wyników badań naukowych, kontakty z przedsiębiorcami dla transferu technologii, budowa uczelnianego systemu transferu technologii),

- oraz zarządzanie własnością intelektualną (ochrona wyników badań naukowych, udostępnianie praw z patentów, umowy licencyjne i wdrożeniowe).

Ponadto, wspieranie przedsiębiorczości, promowanie wyników badań naukowych oraz kreowanie współpracy z biznesem.

Katalog uczelnianych centrów transferu technologii w Polsce prezentuje tabela 1.

Tabela 1. Centra Transferu Technologii w Polsce

\begin{tabular}{|c|c|}
\hline $\begin{array}{l}\text { Centrum Innowacji i Transferu Technologii } \\
\text { Politechnika Białostocka }\end{array}$ & $\begin{array}{l}\text { Dział Transferu Technologii Politechniki } \\
\text { Łódzkiej } \\
\text { Politechnika Łódzka }\end{array}$ \\
\hline $\begin{array}{l}\text { Wschodni Ośrodek Transferu Technologii } \\
\text { Uniwersytet w Białymstoku }\end{array}$ & $\begin{array}{l}\text { Centrum Transferu Technologii } \\
\text { Uniwersytet Łódzki }\end{array}$ \\
\hline $\begin{array}{l}\text { Regionalne Centrum Innowacyjności - Cen- } \\
\text { trum Transferu Technologii przy Uniwersytecie } \\
\text { Technologiczno-Przyrodniczym } \\
\text { im. Jana i Jędrzeja Snniadeckich w Bydgoszczy }\end{array}$ & $\begin{array}{l}\text { Centrum Innowacji i Transferu Technologii } \\
\text { Uniwersytetu Medycznego w Łodzi }\end{array}$ \\
\hline $\begin{array}{l}\text { Centrum Transferu Technologii } \\
\text { Państwowa Wyższa Szkoła Zawodowa } \\
\text { w Elblągu }\end{array}$ & $\begin{array}{l}\text { Centrum Przedsiębiorczości i Transferu } \\
\text { Technologii (CPTT) } \\
\text { Uniwersytet Zielonogórski }\end{array}$ \\
\hline $\begin{array}{l}\text { Samodzielne Stanowisko ds. Innowacji - } \\
\text { BUSINESS POINT } \\
\text { Gdański Uniwersytet Medyczny }\end{array}$ & $\begin{array}{l}\text { Ośrodek Jakości i Innowacji } \\
\text { Wydział Nauk Technicznych Uniwersytetu } \\
\text { Warmińsko-Mazurskiego w Olsztynie }\end{array}$ \\
\hline $\begin{array}{l}\text { Centrum Wiedzy i Przedsiębiorczości } \\
\text { Politechnika Gdańska }\end{array}$ & $\begin{array}{l}\text { Centrum Innowacji i Transferu Technologii } \\
\text { Uniwersytet Warmińsko-Mazurski w Olsztynie }\end{array}$ \\
\hline $\begin{array}{l}\text { Centrum Innowacji i Transferu Technologii } \\
\text { Politechnika Śląska }\end{array}$ & $\begin{array}{l}\text { Dział Nauki i Transferu Technologii Politech- } \\
\text { niki Opolskiej }\end{array}$ \\
\hline $\begin{array}{l}\text { Biuro Współpracy z Gospodarką (Centrum } \\
\text { Innowacji, Transferu Technologii i Rozwoju) } \\
\text { Uniwersytet Śląski }\end{array}$ & $\begin{array}{l}\text { Uczelniane Centrum Innowacji i Transferu } \\
\text { Technologii Uniwersytetu } \\
\text { im. Adama Mickiewicza } \\
\text { Fundacja Uniwersytetu } \\
\text { im. Adama Mickiewicza } \\
\text { Centrum Innowacji, Rozwoju i Transferu Tech- } \\
\text { nologii Politechniki Poznańskiej }\end{array}$ \\
\hline $\begin{array}{l}\text { Centrum Transferu Wiedzy } \\
\text { Park Naukowo-Technologiczny Politechniki } \\
\text { Koszalińskiej }\end{array}$ & $\begin{array}{l}\text { Uniwersyteckie Centrum Transferu Technolo- } \\
\text { gii } \\
\text { Uniwersytet Rzeszowski }\end{array}$ \\
\hline $\begin{array}{l}\text { Centrum Transferu Technologii } \\
\text { Politechnika Krakowska }\end{array}$ & $\begin{array}{l}\text { Regionalne Centrum Innowacji i Transferu } \\
\text { Technologii } \\
\text { Zachodniopomorski Uniwersytet Technolo- } \\
\text { giczny w Szczecinie }\end{array}$ \\
\hline $\begin{array}{l}\text { Centrum Innowacji, Transferu Technologii } \\
\text { i Rozwoju Uniwersytetu CITTRU } \\
\text { Uniwersytet Jagielloński }\end{array}$ & $\begin{array}{l}\text { Centrum Transferu Technologii Morskich } \\
\text { Akademia Morska w Szczecinie }\end{array}$ \\
\hline
\end{tabular}


Tabela 1 (cd.)

\begin{tabular}{|l|l|}
\hline $\begin{array}{l}\text { Centrum Transferu Technologii AGH } \\
\text { Akademia Górniczo-Hutnicza im. St. Staszica } \\
\text { w Krakowie }\end{array}$ & $\begin{array}{l}\text { Interdyscyplinarne Centrum Nowoczesnych } \\
\text { Technologii UMK w Toruniu } \\
\text { Uniwersytet Mikołaja Kopernika }\end{array}$ \\
\hline $\begin{array}{l}\text { Centrum Transferu Technologii Uniwersytetu } \\
\text { Rolniczego im. Hugona Kołłątaja w Krakowie } \\
\text { Uniwersytet Rolniczy im. Hugona Kołłątaja } \\
\text { w Krakowie }\end{array}$ & $\begin{array}{l}\text { Instytut Badań Stosowanych Politechniki } \\
\text { Warszawskiej sp. z o. o. } \\
\text { (Centrum Transferu Technologii i Rozwoju } \\
\text { Przedsiębiorczości) } \\
\text { Politechnika Warszawska }\end{array}$ \\
\hline $\begin{array}{l}\text { Preinkubator Przedsiębiorczości Akademickiej } \\
\text { CTE/UR w Krakowie } \\
\text { Centrum Transferu Ekotechnologii sp. z o.o. }\end{array}$ & $\begin{array}{l}\text { Bio\&Technology Innovations Platform } \\
\text { Ośrodek Transferu Technologii BioTech-IP } \\
\text { Międzynarodowy Instytut Biologii Molekularnej }\end{array}$ \\
\hline $\begin{array}{l}\text { Lubelskie Centrum Transferu Technologii } \\
\text { Politechnika Lubelska }\end{array}$ & $\begin{array}{l}\text { Centrum Innowacji i Transferu Technologii } \\
\text { SGGW } \\
\text { Szkoła Główna Gospodarstwa Wiejskiego }\end{array}$ \\
\hline $\begin{array}{l}\text { Centrum Innowacji i Komercjalizacji Badań } \\
\text { Uniwersytet Marii Curie Skłodowskiej }\end{array}$ & $\begin{array}{l}\text { Uniwersytecki Ośrodek Transferu } \\
\text { Technologii UW }\end{array}$ \\
\hline $\begin{array}{l}\text { Centrum Informatyzacji i Bezpieczeństwa } \\
\text { Transportu } \\
\text { Wyższa Szkoła Ekonomii i Innowacji } \\
\text { w Lublinie }\end{array}$ & $\begin{array}{l}\text { Centrum Innowacji i Transferu Technologii } \\
\text { Uniwersytet Medyczny we Wrocławiu }\end{array}$ \\
\hline $\begin{array}{l}\text { Centrum Transferu Technologii Politechniki } \\
\text { Łódzkiej }\end{array}$ & $\begin{array}{l}\text { Centrum Transferu Technologii } \\
\text { Pomorski Uniwersytet Medyczny w Szczecinie }\end{array}$ \\
\hline
\end{tabular}

Źródło: opracowanie własne na podstawie danych Stowarzyszenia Organizatorów Ośrodków Innowacji i Przedsiębiorczości, http://www.sooipp.org.pl/centra-transferu-technologii.

Mogą one zrzeszać się w ramach ogólnopolskiej inicjatywy pn. Porozumienie Akademickich Centrów Transferów Technologii. Celem Porozumienia jest między innymi integracja środowiska zajmującego się transferem wiedzy i technologii w warunkach akademickich, wymiana wiedzy, doświadczeń i dobrych praktyk, czy wspólna reprezentacja członków wobec organów administracji publicznej oraz innych podmiotów działających na rzecz innowacji i współpracy nauki z biznesem ${ }^{25}$.

Dane Polskiej Agencji Inwestycji i Handlu wskazują, że obecnie w Polsce funkcjonuje około 77 centrów badawczo-rozwojowych zatrudniających kilka tysięcy polskich naukowców i specjalistów. Najwięcej pracuje dla sektora teleinformatycznego, motoryzacyjnego, chemicznego, lotniczego, spożywczego czy IT. Centra te zlokalizowane są głównie w dużych ośrodkach miejskich $\mathrm{z}$ rozbudowanym zapleczem akademickim, rozwiniętą infrastrukturą, stwarzających atrakcyjne warunki życia dla potencjalnych pracowników, ale również ogromnym zainteresowaniem cieszą się mniejsze, wspomniane wcześniej ośrodki akademickie $^{26}$.

Ponadto, w Polsce działają centra B+R, które funkcjonują jako oddziały globalnych koncernów. Są to m.in: Oracle, Samsung, Faurecia, GlaxoSmithKline, Microsoft, Volvo,

\footnotetext{
25 http://www.pactt.pl/.

26 http://www.paiz.gov.pl/sektory/badawczo_rozwojowy\#.
} 
Capgemini, IBM, ABB, Lurgi, Google czy Bosch Siemens. W branży informatycznej i lotniczej laboratoria $\mathrm{B}+\mathrm{R}$ działają na terenie polskich uczelni i jednostek badawczo-rozwojowych: Intel na Politechnice Gdańskiej, United Technologies Corporation na Politechnice Rzeszowskiej, Lockheed Martin, a także GE Aircraft Engines w warszawskim Instytucie Lotnictwa $^{27}$.

Pozytywne doświadczenia i doskonałe rezultaty firm posiadających swoje centra $B+R$ sprawiają, że większość decyduje się na zwiększenie zakresu i skali działalności. Wśród nich znalazły się takie firmy jak: Samsung, NSN, Kainos, FMC Technologies czy polskie firmy takie jak Transition Technologies czy SMT Software. Dwie ostatnie firmy zdecydowały się na wybór mniejszych ośrodków akademickich, takich jak Białystok czy Lublin dla rozwoju swoich centrów rozwoju oprogramowania, co świadczy o tym, że i mniejsze ośrodki akademickie mogą stanowić zaplecze kadrowe dla takich przedsięwzięć. Według Polskiej Agencji Inwestycji i Handlu w ciągu ostatnich lat obserwuje się wzrost zainteresowania otwieraniem centrów B+R zarówno w sektorze produkcji (przykładem jest Delphi w Krakowie, czy Rockwell Automation w Katowicach) jak i w sektorze usług biznesowych, gdzie wg danych Polskiej Agencji Informacji i Inwestycji Zagranicznych (PAIiIZ) zostało utworzonych ponad 500 centrów, z czego blisko 182 to centra $B+R$. W procesach $B+R$ we wspomnianym sektorze zatrudnienie znalazło już blisko 33 tys. osób ${ }^{28}$.

Potencjał gospodarczy Polski jest wciąż doceniany przez zagranicznych inwestorów, o czym świadczy stały napływ kapitału zagranicznego w celu ulokowania swoich centrów, w tym centrów badawczo-rozwojowych $(\mathrm{B}+\mathrm{R})^{29}$.

\section{FIRMY Z KAPITAŁEM ZAGRANICZNYM W POLSCE - POTENCJAŁ DLA TRANSFERU TECHNOLOGII}

BIZ traktuje się jako zasadniczą formę transferu technologii. Istotną cechą tego typu inwestycji jest transfer wiedzy produkcyjnej, rozwiązań technologicznych, transfer nowych technologii, know-how itp. ${ }^{30}$ Międzynarodowe koncerny w coraz większym stopniu dostrzegają Polskę jako dogodne miejsce do lokowania inwestycji wymagających zaawansowanych zasobów kapitału ludzkiego. Dla wielu zagranicznych inwestorów Polska stanowi źródło dobrze wykwalifikowanych, ale też tanich pracowników. Prócz stosunkowo niskich kosztów podmioty zagraniczne przyciągają ulgi oraz niespotykane już w Unii Europejskiej specjalne strefy ekonomiczne. W Polsce z roku na rok rośnie liczba firm z kapitałem zagranicznym. Średnie tempo zmian w analizowanym okresie wyniosło niecałe $1 \% \mathrm{w}$ przypadku liczby firm z kapitałem zagranicznym i $4 \%$ w przypadku osób zatrudnionych w tych podmiotach - tabela 2.

\footnotetext{
27 Ibidem.

${ }^{28}$ Ibidem

${ }^{29}$ Ibidem.

30 J. Wiśniewska, Bezpośrednie inwestycje zagraniczne w procesie kreowania innowacyjności $i$ konkurencyjności przedsiębiorstw, Studia i Prace Wydziału Nauk Ekonomicznych i Zarządzania nr 21, http://www.wneiz.pl/nauka_wneiz/sip/sip21-2011/SiP-21-5.pdf.
} 
Tabela 2. Podmioty z kapitałem zagranicznym w Polsce w latach 2012-2015

\begin{tabular}{|l|r|r|r|r|}
\hline \multirow{2}{*}{\multicolumn{1}{|c|}{ Wyszczególnienie }} & \multicolumn{4}{|c|}{ Lata } \\
\cline { 2 - 5 } & $\mathbf{2 0 1 2}$ & $\mathbf{2 0 1 3}$ & $\mathbf{2 0 1 4}$ & \multicolumn{1}{c|}{$\mathbf{2 0 1 5}$} \\
\hline Liczba podmiotów & 25914 & 26128 & 26464 & 25961 \\
\hline Liczba pracujących & 1571235 & 1628516 & 1747811 & 1818465 \\
\hline $\begin{array}{l}\text { Kapitał podstawowy } \\
\text { (w mln zł) }\end{array}$ & 206992,3 & 209130,0 & 215594,8 & 222533,6 \\
\hline $\begin{array}{l}\text { w tym krajowy } \\
\text { (w mln zł) }\end{array}$ & 179372,3 & 188243,1 & 195796,8 & 203897,8 \\
\hline $\begin{array}{l}\text { w tym zagraniczny } \\
\text { (w mln zł) }\end{array}$ & 53062,7 & 51303,6 & 57969,5 & 64037,0 \\
\hline $\begin{array}{l}\text { Nakłady na nowe środki } \\
\text { trwałe (w mln zł) }\end{array}$ & 15435,3 & 13715,5 & 12949,0 \\
\hline
\end{tabular}

Źródło: Działalność gospodarcza podmiotów z kapitałem zagranicznym w 2015 r., Informacje i opracowania statystyczne, GUS, Warszawa 2016, http://stat.gov.pl/obszary-tematyczne/podmioty-gospodarcze-wyniki-finansowe/przedsiebiorstwa-niefinansowe/dzialalnosc-gospodarcza-podmiotow-z-kapitalem-zagranicznym-w-2015-r-,4,11.html.

W 2015 roku badana przez GUS zbiorowość podmiotów z udziałem kapitału zagranicznego liczyła 25961 jednostek, tj. o 1,9\% mniej niż w 2014. Struktura podmiotów pod względem form prawnych podmiotów kształtowała się następująco: 92,2\% stanowiły spółki z ograniczoną odpowiedzialnością, 3,7\% - spółki akcyjne, 2,5\% - spółki komandytowe, $0,8 \%$ - oddziały przedsiębiorców zagranicznych, a $0,8 \%$ - pozostałe formy prawne. Z punktu widzenia wielkości podmiotów, dominowały jednostki małe - do 49 pracujących, które stanowiły 83,8\% ogólnej liczby przedsiębiorstw, w tym mikro - przedsiębiorstwa o liczbie pracujących do 9 osób - 66,0\%. Do podmiotów o liczbie pracujących od 50 do 249 osób należało $11,0 \%$ całej zbiorowości przedsiębiorstw, a do jednostek dużych, o liczbie pracujących 250 i więcej osób - 5,2\%. Działalność profesjonalną, naukową i techniczną prowadziło 9,3\% przedsiębiorstw. Podobnie jak w 2014 roku, ponad 1/3 podmiotów z kapitałem zagranicznym miała siedzibę w województwie mazowieckim - 38,6\%. W porównaniu z rokiem poprzednim przyrost liczby podmiotów odnotowano między innymi w województwie podkarpackim (o 7,1\%), lubelskim (o 3,1\%) i w małopolskim (o 0,5\%). Podmioty, w których suma kapitału zagranicznego przekraczała 50\% kapitału podstawowego, stanowiły $85,7 \%$ ogółu (wobec $86,3 \%$ rok wcześniej). W zbiorowości tej przeważały jednostki w całości należące do inwestorów zagranicznych $(82,3 \%)$. W grupie podmiotów z przewagą kapitału zagranicznego $87,6 \%$ to podmioty, w których ponad $50 \%$ kapitału podstawowego należało do jednego udziałowca zagranicznego. Jak wskazują dane GUS, w całej populacji podmiotów z udziałem kapitału zagranicznego stanowiły one $75,0 \%{ }^{31}$.

Najwięcej firm z kapitałem zagranicznym działa w działalnościach handlowej i przetwórstwa przemysłowego. Z kolei największy udział nowych firm w postaci greenfield,

${ }^{31}$ Działalność gospodarcza podmiotów z kapitatem zagranicznym w 2015 r., Informacje i opracowania statystyczne, Warszawa 2016, s. 15, http://stat.gov.pl/obszary-tematyczne/podmioty-gospodarcze-wyniki-finansowe/przedsiebiorstwa-niefinansowe/dzialalnosc-gospodarcza-podmiotow-z-kapitalem-zagranicznym-w-2015-r-,4,11.html?contrast=black-yellow. 
czyli od podstaw jest w usługach, edukacji, handlu. Podmioty greenfields w 2014 r. stanowiły ponad $80 \%$ firm nowo powstałych, co jest zjawiskiem bardzo cennym dla całej polskiej gospodarki, ponieważ zmniejsza lukę inwestycyjną, czy wpływa znacząco na modernizację oraz poprawę konkurencyjności gospodarki kraju.

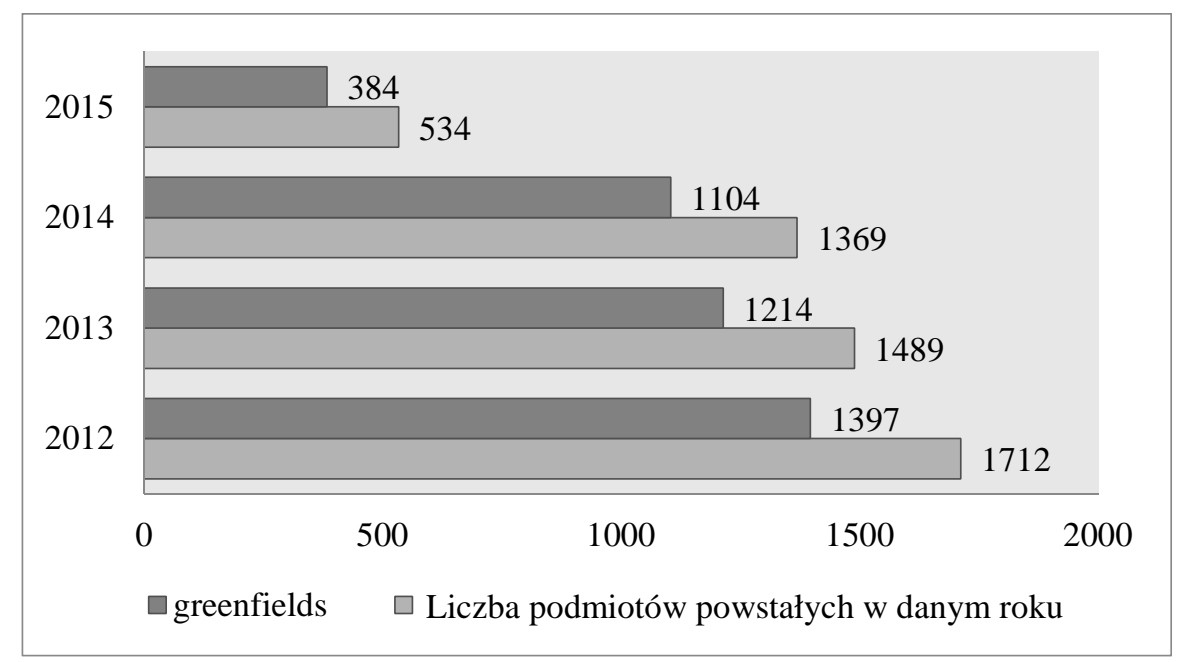

Wykres 1. Struktura podmiotów z kapitałem zagranicznym powstałych w latach 2012-2015 $\mathrm{z}$ uwzględnieniem inwestycji typu greenfields

Źródło: opracowano na podstawie Działalność gospodarcza podmiotów z kapitatem zagranicznym w 2012r., 2013r., 2014r., 2015r. Informacje i opracowania statystyczne, Warszawa 2013, 2014, 2015, http://stat.gov.pl/publikacje/szukaj.html?letter=D.

Największe nakłady na inwestycje wśród firm z kapitałem zagranicznym w 2015 r. ponoszono w województwach: mazowieckim, wielkopolskim, śląskim i dolnośląskim - tabela 3. W samym mazowieckim firmy dokonały inwestycji na $4004 \mathrm{mln}$ zł.

Szeroko rozumiane zmiany gospodarcze w Polsce wpłynęły na zwiększenie zainteresowania polską gospodarką ze strony podmiotów zagranicznych. Istotne okazały się zmiany w prawie, w tym Ustawa o spółkach z udziałem zagranicznym z 1991 r. dopuszczająca prowadzenie przez inwestorów zagranicznych działalności w formie spółki akcyjnej lub spółki z ograniczoną odpowiedzialnością. Ważne znaczenie miało również wejście w życie ustawy Prawo działalności gospodarczej z 1999 r., gdzie w art. 6 pkt 2 zapisano, że osoby zagraniczne mogą na terytorium Rzeczypospolitej Polskiej podejmować i wykonywać działalność gospodarczą na takich samych zasadach jak przedsiębiorcy krajowi. Istotnym czynnikiem, zwiększającym atrakcyjność inwestycyjną Polski, była również akcesja do Unii Europejskiej. W początkowym okresie to podmioty zagraniczne importowały produkty i komponenty niezbędne do produkcji w Polsce. W kolejnych latach to polskie przedsiębiorstwa zaczęły produkować dobra na potrzeby podmiotów z kapitałem zagranicznym, tworząc i umacniając swoją pozycję na rynku krajowym, dzięki czemu mogły z czasem podjacc ekspansję zagraniczną. Polskie przedsiębiorstwa otrzymały impuls do wdrażania 
nowych rozwiązań technicznych, co zwiększało krajowy popyt inwestycyjny, wpływając pozytywnie na tempo wzrostu gospodarczego ${ }^{32}$.

Tabela 3. Nakłady inwestycyjne poniesione na pozyskanie aktywów trwałych w mln zł w latach 2012-2015

\begin{tabular}{|l|c|c|c|c|}
\hline \multicolumn{5}{|c|}{ Liczba podmiotów ponoszących nakłady inwestycyjne } \\
\hline \multicolumn{1}{|c|}{ Województwa } & $\mathbf{2 0 1 2}$ & $\mathbf{2 0 1 3}$ & $\mathbf{2 0 1 4}$ & $\mathbf{2 0 1 5}$ \\
\hline Ogółem & 11506 & 11479 & 11500 & 11363 \\
\hline Dolnośląskie & 1122 & 1110 & 1109 & 1087 \\
\hline Kujawsko-pomorskie & 311 & 307 & 294 & 284 \\
\hline Lubelskie & 168 & 162 & 179 & 178 \\
\hline Lubuskie & 345 & 343 & 336 & 325 \\
\hline Łódzkie & 507 & 520 & 502 & 486 \\
\hline Małopolskie & 679 & 645 & 661 & 679 \\
\hline Mazowieckie & 4025 & 4039 & 4033 & 4004 \\
\hline Opolskie & 217 & 219 & 220 & 4004 \\
\hline Podkarpackie & 198 & 202 & 199 & 193 \\
\hline Podlaskie & 76 & 76 & 72 & 78 \\
\hline Pomorskie & 662 & 673 & 682 & 667 \\
\hline Śląskie & 1135 & 1154 & 1150 & 1124 \\
\hline Siętokrzyskie & 101 & 94 & 95 & 83 \\
\hline Warmińsko-mazurskie & 116 & 119 & 126 & 123 \\
\hline Wielkopolskie & 1197 & 1165 & 1189 & 1170 \\
\hline Zachodniopomorskie & 647 & 651 & 653 & 664 \\
\hline
\end{tabular}

Źródło: opracowano na podstawie Działalność gospodarcza podmiotów z kapitatem zagranicznym $w 2012$ r., 2013 r., 2014 r., 2015 r....

Jednym z efektów obecności firm z kapitałem zagranicznym zwłaszcza BIZ w polskiej gospodarce jest wiele korzystnych efektów zewnętrznych, które mogą prowadzić do poprawy sytuacji przedsiębiorstw, również krajowych. Jednym z nich jest transfer technologii. Tzw. efekt dyfuzji technologii z firm z kapitałem zagranicznym do firm z krajowych może mieć charakter wertykalny, tzn. firmy krajowe uczą się poprzez współpracę z firmami zagranicznymi, a może mieć charakter horyzontalny, gdy przedsiębiorstwa tej samej branży naśladują firmy zagraniczne, by sprostać konkurencji i utrzymać się na rynku - tzw. wewnątrzbranżowy transfer technologii ${ }^{33}$.

W analizowanym okresie w Polsce rokrocznie zwiększała się liczba firm z kapitałem zagranicznym. W 2015 r. aktywnych spółek z udziałem kapitału zagranicznego powstało 6706 - tabela 4, a w pierwszej połowie 2016 r. -3588.

32 Polska 2015. Raport o stanie gospodarki, Ministerstwo Gospodarki Departament Strategii i Analiz, Warszawa 2015, s. 247, https://www.mr.gov.pl/media/15346/Raport_o_stanie_gospodarki_2015_ pl.pdf.

33 D. Ciołek, S. Umiński, Jak mierzyć wptyw bezpośrednich inwestycji zagranicznych na produktywność przemystu w Polsce. Prace i Materiały Wydziału Zarządzania Uniwersytetu Gdańskiego 5/2007, s. 109. 
Tabela 4. Nowe firmy z kapitałem zagranicznym w Polsce w latach 2012-2015

\begin{tabular}{|c|c|c|}
\hline Rok & $\begin{array}{c}\text { Liczba nowych firm } \\
\text { z kapitałem zagranicznym }\end{array}$ & $\begin{array}{c}\text { Zmiana w stosunku } \\
\text { do poprzedniego roku }\end{array}$ \\
\hline 2015 & 6706 & 52,7 \\
\hline 2014 & 4390 & 20,01 \\
\hline 2013 & 3658 & 6,03 \\
\hline 2012 & 3450 & 15,12 \\
\hline
\end{tabular}

Źródło: http://www.coig.com.pl/inwestorzy-zagraniczni-w-Polsce-w_2016-r.php.

Najsilniej nowych inwestorów zagranicznych przyciągają: woj. mazowieckie 44,40\%, dolnośląskie $8,19 \%$, wielkopolskie $7,85 \%{ }^{34}$. Nowo rejestrowane firmy z udziałem kapitału zagranicznego w 2016 r. mają swoje siedziby w 426 miejscowościach. Najwięcej firm ma siedzibę w Warszawie (1415 firm), Krakowie (398) i Wrocławiu (198) - tabela 5.

Tabela 5. Miejscowości, w których jako siedzibę wybrało minimum 20 firm z udziałem kapitału zagranicznego w $2016 \mathrm{r}$.

\begin{tabular}{|l|c|}
\hline \multicolumn{1}{|c|}{ Miejscowość } & Liczba firm \\
\hline Warszawa & 1415 \\
\hline Kraków & 398 \\
\hline Wrocław & 198 \\
\hline Poznań & 114 \\
\hline Wólka Kosowska & 100 \\
\hline Lublin & 88 \\
\hline Gdańsk & 71 \\
\hline Rzeszów & 67 \\
\hline Przemyśl & 60 \\
\hline Łódź & 56 \\
\hline Katowice & 51 \\
\hline Szczecin & 45 \\
\hline Bielsko-Biała & 33 \\
\hline Piaseczno & 28 \\
\hline Białystok & 22 \\
\hline Bydgoszcz & 20 \\
\hline
\end{tabular}

Źródło: http://www.coig.com.pl/inwestorzy-zagraniczni-w-Polsce-w_2016-r.php.

\footnotetext{
${ }^{34}$ http://www.coig.com.pl/inwestorzy-zagraniczni-w-polsce.php.
} 
Jak wynika z raportu Polska 2015. Raport o stanie gospodarki ${ }^{35}$, firmy z udziałem zagranicznego kapitału i podejmowane przez nie działania inwestycyjne sprzyjają zmianom jakościowym, tj. wzrostowi zaawansowania technicznego prowadząc do wzrostu efektywności, dyfuzji technologii, produkcji i eksportu dóbr kapitałochłonnych, modernizacji przemysłu i procesów produkcyjnych, a także kształtują rozwój sektora usług. Firmy z kapitałem zagraniczny zwłaszcza w postaci BIZ są istotnym inicjatorem innowacyjnych przedsięwzięć, stymulowały i ułatwiały wdrażanie nowych rozwiązań technologicznych. Obecnie, coraz większą rolę w polskiej gospodarce odgrywa sektor usług, w tym nowoczesnych usług biznesowych. Liczba centrów usługowych wzrosła do 532 w kwietniu 2015. Centra te należą do 356 inwestorów. Zatrudniają one już 150 tys. pracowników, o $36 \%$ więcej niż w 2013 roku. W świetle danych Raportu Polska jest liderem w Europie pod względem świadczenia usług biznesowych dla globalnych przedsiębiorstw, a w kilku najbliższych latach nastąpi wzrost inwestycji w tym sektorze.

Z punktu widzenia potencjalnego udziału uczelni we wspólnych przedsięwzięciach badawczych ważne są nie tylko nakłady inwestycyjne, ale i działalność eksportowa firm z udziałem kapitału zagranicznego. W 2015 roku 11312 podmiotów z kapitałem zagranicznym eksportowało swoje produkty lub towary i materiały, co stanowiło 43,6\% badanej zbiorowości podmiotów z udziałem kapitału zagranicznego. Wartość eksportu zrealizowanego przez wszystkie podmioty z kapitałem zagranicznym w 2015 r. wyniosła 429 061,5 mln zł i była o 7,7\% wyższa niż przed rokiem. W strukturze eksportu dominował eksport wyrobów - 71,0\% wartości eksportu ogółem. Pozostała część eksportu przypadła na eksport usług - 16,4\%. Dominującą część eksportu zrealizowały podmioty zajmujące się przetwórstwem przemysłowym $(77,8 \%)^{36}$.

Rola firm z kapitałem zagranicznym w polskiej gospodarce oraz jej znaczenie dla rozwoju i pogłębienia współpracy z uczelnianymi centrami transferu technologii wynika m.in.: ze zwiększenia transmisji wiedzy produkcyjnej, rozwiązań technologicznych, transferu nowych technologii, know-how oraz możliwości adaptacja nowoczesnych technik zarządzania. Jednak możliwości rozwojowe gospodarki i funkcjonujących w niej podmiotów są ograniczone poprzez dotychczasowe osiągnięcia i poniesione nakłady, zwłaszcza na pozyskanie wiedzy i technologii.

Wielkość i rodzaj korzyści płynących z BIZ zależy od tego, czy inwestycje mają charakter horyzontalny (zorientowany na dostęp do rynku zbytu lub produktów firmy), czy wertykalny (ukierunkowane na wykorzystanie niskich cen czynników i nakładów produkcyjnych). W pierwszym przypadku transfer technologii służy jedynie działalności filii na określonym rynku, często transferowana technologia nie jest najnowocześniejsza, ale wystarczająco konkurencyjna w warunkach słabej rywalizacji. Z kolei, w przypadku BIZ typu wertykalnego istniejące od początku powiązania kooperacyjne między filiami a lokalnymi przedsiębiorstwami skutkują dużo szybszym i większym oddziaływaniem transferu techno-

${ }^{35}$ Polska 2015. Raport o stanie gospodarki, Ministerstwo Gospodarki Departament Strategii i Analiz, Warszawa 2015, s. 244-246, https://www.mr.gov.pl/media/15346/Raport_o_stanie_gospodarki_ 2015_pl.pdf.

${ }^{36}$ Działalność gospodarcza podmiotów z kapitatem zagranicznym w 2015 r. Informacje i opracowania statystyczne, GUS, Warszawa 2016, http://stat.gov.pl/obszary-tematyczne/podmioty-gospodarcze-wyniki-finansowe/przedsiebiorstwa-niefinansowe/dzialalnosc-gospodarcza-podmiotow-zkapitalem-zagranicznym-w-2015-r-,4,11.html?contrast=black-yellow. 
logii na krajowe zdolności technologiczne ${ }^{37}$. „Skala i zakres realnie występujących pozytywnych efektów BIZ zależy od zdolności do absorpcji nowoczesnych technologii” ${ }^{38}$.

\section{WNIOSKI KOŃCOWE}

Na bazie dokonanej analizy pozyskanego materiału teoretyczno-empirycznego można wnioskować, iż:

- w procesie transferu technologii i wiedzy oraz rozwoju innowacji kluczową rolę odgrywają uczelniane centra transferu technologii, których liczebność oraz układ przestrzenny i powiązania instytucjonalne, stanowią dobry potencjał do dynamizowania procesu transferu z korzyścią dla regionów i całej gospodarki kraju;

- przedsiębiorstwami, które dysponują dużym potencjałem komercjalizacyjnym między innymi ze względu na fakt, iż wprowadzają innowacyjne rozwiązania techniczne i technologiczne są podmioty z kapitałem zagranicznym;

- współpraca firm z kapitałem zagranicznym z uczelnianymi i pozauczelnianymi centrami transferu technologii może wpłynąć pozytywnie na wsparcie i szeroko rozumianą aktywizację środowiska naukowego oraz rozwój i podniesienie innowacyjności regionu i gospodarki.

Identyfikowane w opracowaniu możliwości komercjalizacji dotyczą z jednej strony wymiernych efektów instytucjonalnych procesu budowy podstaw współpracy nauka - biznes, biznes - nauka oraz niewykorzystanych w opinii autorów (brak szczegółowych wyników badań krajowych w tym zakresie) zasobów firm z kapitałem zagranicznym w procesie transferu technologii i wiedzy z uczelni krajowych.

Niniejsze rozważania stanowią wstęp do dalszych badań empirycznych nad możliwościami współpracy przedsiębiorstw z kapitałem zagranicznym z centrami transferu technologii w Polsce.

\section{LITERATURA}

[1] Centra Transferu Technologii http://www.pi.gov.pl/iob/chapter_86470.asp.

[2] Ciołek D., Umiński S., Jak mierzyć wptyw bezpośrednich inwestycji zagranicznych na produktywność przemystu w Polsce. Prace i Materiały Wydziału Zarządzania Uniwersytetu Gdańskiego 5/2007.

[3] Działalność gospodarcza podmiotów z kapitatem zagranicznym w 2015 r., Informacje i opracowania statystyczne, GUS, Warszawa 2016, http://stat.gov.pl/obszary-tematyczne/podmioty-gospodarcze-wyniki-finansowe/przedsiebiorstwa-niefinansowe/dzialalnosc-gospodarcza-podmiotow-z-kapitalem-zagranicznym-w-2015-r-,4,11.html?contrast=black-yellow.

[4] Dziatalność gospodarcza podmiotów z kapitatem zagranicznym w 2015 r., Informacje i opracowania statystyczne, GUS, Warszawa 2016, http://stat.gov.pl/obszary-tematyczne/podmioty-gospodarcze-wyniki-finansowe/przedsiebiorstwa-niefinansowe/dzialal-

37 A. Zorska, Korporacje transnarodowe. Przemiany, oddziatywania, wyzwania, Warszawa 2007, s. 292-293.

38 J. Wiśniewska, Bezpośrednie inwestycje zagraniczne w procesie kreowania innowacyjności i konkurencyjności przedsiębiorstw. Studia i Prace Wydziału Nauk Ekonomicznych i Zarządzania nr 21, s. 64, http://www.wneiz.pl/nauka_wneiz/sip/sip21-2011/SiP-21-5.pdf. 
nosc-gospodarcza-podmiotow-z-kapitalem-zagranicznym-w-2015-r-,4,11.html?contrast= =black-yellow.

[5] European Innovation Scoreboard 2017, http://ec.europa.eu/DocsRoom/documents/24829

[6] Foreign direct investment for development. Maximising benefits, minimising costs, Overview, https://www.oecd.org/investment/investmentfordevelopment/1959815.pdf

[7] Innowacje i transfer technologii. Stownik pojęć, red. K.B. Matusiak, Polska Agencja Rozwoju Przedsiębiorczości, Warszawa 2011, https://www.parp.gov.pl/files/74/81/469/12812. pdf.

[8] Kwiek M., Polskie szkolnictwo wyższe a transformacje uniwersytetów w Europie https://repozytorium.amu.edu.pl/jspui/bitstream/10593/10335/1/Kwiek_Appendix_2010.pdf.

[9] Matusiak K.B., Guliński J., System transferu technologii i komercjalizacja wiedzy - sity motoryczne i bariery, Polska Agencja Rozwoju Przedsiębiorczości, PARP, Poznań - Łódź - Wrocław - Warszawa 2010, ://www.kigeit.org.pl/FTP/PRCIP/Literatura/072_System_transferu_technologii_i_komercjalizacji_wiedzy_w_Polsce_PARP_2010.pdf.

[10] Nowoczesne uczelnie rada na kryzys, Ministerstwo Nauki i Szkolnictwa Wyższego, https://www.google.pl/search?q=Nowoczesne+uczelnie+rad\%C4\%85+na+kryzys\&oq= $=$ Nowoczesne+uczelnie $+\mathrm{rad} \% \mathrm{C} 4 \% 85+$ na + kryzys\&aqs=chrome..69i57.995j0j7\&sourceid=chrome\&espv=210\&es_sm=122\&ie $=$ UTF- 8 .

[11] Olifirowicz M. (red.), Bezpośrednie inwestycje zagraniczne na świecie i w Polsce: tendencje, determinanty $i$ wptyw na gospodarke, UNCTAD, Ministerstwo Gospodarki, Instytut Technologii Eksploatacji, Warszawa 2002.

[12] Orłowski W.M., Komercjalizacja badań naukowych w Polsce. Bariery i możliwości ich przetamania, Warszawa 2013, http://www.biznes.edu.pl/upload/files/komercjalizacja-badan-naukowych-w-polsce---prof.-w.-orlowski.pdf.

[13] Pietrzyk I., Polityka regionalna Unii Europejskiej i regiony w państwach członkowskich, PWN, Warszawa 2002.

[14] Polska 2015. Raport o stanie gospodarki, Ministerstwo Gospodarki Departament Strategii i Analiz, Warszawa 2015, https://www.mr.gov.pl/media/15346/Raport_o_stanie_gospodarki_2015_pl.pdf.

[15] Potencjat innowacyjny gospodarki: uwarunkowania, determinanty, perspektywy, NBP, Warszawa 2016, https://www.nbp.pl/aktualnosci/wiadomosci_2016/20160530_Raport_innowacyjnosc.pdf.

[16] Przedsiębiorczość w Polsce, Ministerstwo Rozwoju Departament Strategii Rozwoju, Warszawa 2016, https://www.mr.gov.pl/media/27643/Przedsiebiorczosc_w_Polsce.pdf.

[17] Rymarczyk J., Biznes międzynarodowy, PWE, Warszawa 2012.

[18] The Global Innovation Index 2017, Innovation Feeding the World, https://www.globalinnovationindex.org/.

[19] Szewc-Rogalska A., Leszczyńska M., Kapitat zagraniczny jako czynnik rozwoju i modernizacji gospodarki, http://ur.edu.pl/pliki/Zeszyt19/15.pdf.

[20] Ustawa z dnia 27 lipca 2005 r. Prawo o szkolnictwie wyższym (Dz.U. z 2005 r., nr 164, poz. 1365).

[21] Wancio A., Wptyw bezpośrednich inwestycji zagranicznych na innowacyjność gospodarek wschodzacych. Przypadek Indii, Szkoła Główna Handlowa w Warszawie Kolegium Gospodarki Światowej, Warszawa 2015, http://kolegia.sgh.waw.pl/pl/KGS/postepowania/doktoraty/Documents/Wancio\%20-\%20streszczenie\%20polskie.pdf. 
[22] Wiśniewska J., Bezpośrednie inwestycje zagraniczne w procesie kreowania innowacyjności i konkurencyjności przedsiębiorstw, Studia i Prace Wydziału Nauk Ekonomicznych i Zarządzania nr 21, http://www.wneiz.pl/nauka_wneiz/sip/sip21-2011/SiP-21-5.pdf.

[23] Wspótpraca nauki i biznesu. Doświadczenia i dobre praktyki wybranych projektów w ramach Programu Operacyjnego Innowacyjna Gospodarka na lata 2007-2013, red. K. Bromski, PARP, Warszawa 2013, https://www.parp.gov.pl/images/PARP_publications/ pdf/18863.pdf.

[24] Wyżnikiewicz B., Korzyści z obcego kapitału, „Prawo i Gospodarka”, nr 54/2001.

[25] Zadura-Lichota P. (red.), Innowacyjna przedsiębiorczość w Polsce. Odkryty i ukryty potencjat polskiej innowacyjności, PARP 2015, https://www.parp.gov.pl/files/74/81/806/22522. pdf.

[26] Zorska A., Korporacje transnarodowe. Przemiany, oddziaływania, wyzwania, PWE, Warszawa 2007,

[27] http://stosunki-miedzynarodowe.pl/slownik/55-i/539-instytucjonalizacja.

[28] http://www.coig.com.pl/inwestorzy-zagraniczni-w-polsce.php.

[29] http://www.coig.com.pl/inwestorzy-zagraniczni-w-Polsce-w_2016-r.php.

[30] http://www.pactt.pl/.

[31] http://www.paiz.gov.pl/regiony/wojewodztwa/mazowieckie\#.

[32] http://www.paiz.gov.pl/sektory/badawczo_rozwojowy\#.

[33] http://www.pi.gov.pl/iob/chapter_86470.asp.

[34] http://www.coig.com.pl/inwestorzy-zagraniczni-w-polsce.php.

[35] http://www.sooipp.org.pl/centra-transferu-technologii.

\section{ASSESSMENT OF THE POSSIBILITY OF COOPERATION WITH FOREIGN CAPITAL COMPANIES WITH TECHNOLOGY TRANSFER CENTERS}

Numerous studies show that acceleration of internationalization of economic activity by foreign investment also fosters the rational use of capital, labor and technology, and transformed by foreign investment enterprises improving their financial situation. Foreign Direct Investment (FDI) as an integral part of an open international economic system are often the main catalyst for these changes. However, the benefits from foreign direct investment do not increase automatically and evenly in particular countries, sectors and local communities. In many developing countries, the attraction of foreign direct investment and reaping full benefits from it in terms of development are shaped by national policies and international investment structures. The aim of foreign direct investment is to exert a lasting influence of a direct investor on an economic operator in another country, which at the same time causes a long lasting relationship between the investor and the investment entity. The purpose of this paper is to point out the opportunities, i.e. the premises, benefits and barriers of cooperation between companies with foreign capital and technology transfer centers, in particular universities. On the basis of the analysis of the collected theoretical and empirical material it was stated that: companies can achieve competitive advantage by working closely with the environment and scientific research, and in the process of commercialization and innovation the key role play, among others, technological and industrial parks, technology transfer centers, business incubators and regional development agencies. Enterprises, that significantly improve the competitiveness of the region, introduce new technical and technological solutions are entities with foreign capital. In turn, the cooperation of companies with foreign capital 
with technology transfer centers and other business environment institutions can positively influence the support and activation of the scientific community as well as the development and improvement of the regional and economic innovativeness.

Keywords: Companies with foreign capital, technology transfer, innovation, technology transfer centers.

DOI: $10.7862 /$ rz.2017.hss.51

Przestano do redakcji: maj 2017 r.

Przyjęto do druku: wrzesień 2017 r. 